\title{
Effects and mechanism of dexmedetomidine on neuronal cell injury induced by hypoxia-ischemia
}

\author{
Ya-Jun Liu' ${ }^{1,2}$, Duan-Yu Wang ${ }^{2}$, Yong-Jian Yang ${ }^{2}$ and Wei-Fu Lei ${ }^{1 *}$ (D)
}

\begin{abstract}
Background: The present study aims to investigate the protective effects of dexmedetomidine (DMED) on hypoxia ischemia injury induced by oxygen and glucose deprivation (OGD) in PC12 and primary neuronal cells.

Methods: PC12 cells exposed to OGD was used to establish ischemia model. The OGD-induced cell injury was evaluated by alterations of cell viability, apoptosis and expressions of apoptosis-associated proteins. Oxidative stress and expressions of neurotrophic factors after OGD and DMED treatments were also explored. The activation of possible involved signaling pathways were studied after OGD and DMED treatments, along with the addition of inhibitors of these pathways. Finally, the effects of DMED on primary neuronal cells were verified according to the alterations of inflammatory cytokines release and oxidative stress.

Results: DMED obviously increased cell viability and reduced cell apoptosis as well as ratio of Bax/Bcl-2 in OGD-treated PC12 cells. Then, the OGD-induced changes of LDH, MDA, SOD and GSH-Px as well as decreases of neurotrophic factors were all ameliorated by DMED treatment. Key kinases in Notch/NF-kB signaling pathway were up-regulated by OGD, whereas the up-regulations were decreased by DMED. In addition, inhibitor of Notch or NF-KB could augment the effects of DMED on OGD-induced cell injury. Finally, the protective effects of DMED were verified in primary neuronal cells.

Conclusion: DMED had protective effect on OGD-induced PC12 cell injury, depending on its anti-apoptotic, anti-oxidative activity and the inhibition of Notch/NF-KB activation. Our findings suggested that DMED could be used as a potential therapeutic drug for cerebral ischemia.
\end{abstract}

Keywords: Dexmedetomidine, PC12 cells, Apoptosis, Oxidative stress, Notch/NF-kB pathway

\section{Background}

As a common cerebrovascular disease, ischemic stroke is the most common cause of death and adult disability all over the world [1]. Ischemic stroke is characterized by the disturbance of the blood supply to the brain [2]. A blockage of blood flow in an artery, caused by a thrombus or embolus, leads to a sudden reduction of blood flow, resulting in failure of delivering glucose, oxygen, and nutrient, which are important, to the brain [3]. Although thrombolysis becomes an effective agent for the treatment of ischemic stroke, the narrow therapeutic

\footnotetext{
* Correspondence: leiweifu227@126.com

${ }^{1}$ Department of Anesthesiology, Qilu Hospital of Shandong University, No.

107, Wenhua West Road, Jinan, Shandong 250012, China

Full list of author information is available at the end of the article
}

time window makes this agent useless for large proportion of patients [4]. Thus, novel therapeutic methods are urgently needed for the treatment of ischemic stroke.

Neuronal injury induced by cerebral ischemia is a complex process with various mechanisms, including oxidative stress, apoptosis, activation of kinases and changes in gene expression [5, 6]. Oxidative stress plays a critical role in neuronal injury and has close connections with the pathogenesis of various central nervous system diseases such as cerebral ischemia, Parkinson's disease and Alzheimer's disease. Accumulating evidence has reported that oxidative stress could be a therapeutic target of cerebral ischemia [7]. Oxygen-glucose deprivation (OGD) is an in vitro cell model that simulates the in vivo ischemia for exploring the mechanisms 
of neuronal damage induced by ischemia and for the discovery of the potential protective agents for the treatment of ischemia $[8,9]$.

PC12 cell line, derived from rat pheochromocytoma, has been widely used for cell signaling studies, such as cerebral ischemia and neuronal protection studies $[10,11]$. PC12 cells possess the properties of sympathetic neurons with the impact of nerve growth factor [12]. Many studies focused on neurotoxicity [13], amyloid $\beta$-induced cell apoptosis [14] and Alzheimer's disease [15] have been performed by using PC12 cells.

Dexmedetomidine (DMED) is a new type of clinical anesthetic agent, which is used for calmness of tracheal intubation and mechanical ventilation in surgical patients under general anesthesia. Some studies have discovered that DMED has neuroprotective effects with the preconditioning and attenuation of ischemia injury [16, 17]. Another study has reported that DMED could decrease cerebral blood flow [18]. However, the possible involved mechanisms remain unclear. This study was aimed to uncover the neuronal protective mechanisms of DMED in PC12 cells or primary hippocampal neuronal cells with OGD.

\section{Methods}

\section{Cell culture of PC12 and primary hippocampal neuronal} cells

PC12 cells (American Type Culture Collection, Manassas, VA, USA) were cultured in DMEM containing L-glutamine, $10 \%$ fetal bovine serum, $100 \mathrm{U} / \mathrm{mL}$ penicillin, $5 \%$ horse serum, and $100 \mu \mathrm{g} / \mathrm{mL}$ streptomycin (all from Invitrogen). Cell culture of PC12 cells was performed in humidified atmosphere of $5 \% \mathrm{CO}_{2}$ and $95 \%$ air at $37{ }^{\circ} \mathrm{C}$. Primary hippocampal neuronal cells were isolated from neonatal Wistar rats (2-3 d old, male) following the methods described previously [19]. In brief, bilateral hippocampi were isolated carefully, followed by mechanical fragmentation and digestion with $0.25 \%$ trypsin at $37{ }^{\circ} \mathrm{C}$ for $20 \mathrm{~min}$. After centrifugation at $200 \times g$ for $5 \mathrm{~min}$, the isolated cells were collected and resuspended in Dulbecco's modified Eagle medium and Ham's F-12 medium (DMEM/F12; Invitrogen, Burlington, ON, Canada) supplemented with $20 \%$ fetal bovine serum (Invitrogen). Then, the re-suspension containing neurons at a density of $1.0 \times 10^{6}$ cells $/ \mathrm{mL}$ was planted into a cell culture flask, which was pre-coated with $0.1 \mathrm{mg} / \mathrm{mL}$ polyL-lysine (Sigma-Aldrich, St. Louis, MO, USA), and these neurons were cultured at $37{ }^{\circ} \mathrm{C}$ in humidified air with $5 \% \mathrm{CO}_{2}$. The culture medium was exchanged with neurobasal medium supplemented with $2 \% \mathrm{~B} 27,10 \mathrm{mM}$ glutamine and $1 \mathrm{mM}$ sodium pyruvate. All the procedures were approved by the Ethical Committee of Qilu Hospital of Shandong University.

\section{Cell treatments}

To establish OGD-induced hypoxic-ischemic model, the cells were cultured in the DMEM culture medium without glucose, and then incubated in an oxygen-free chamber with $95 \% \mathrm{~N}_{2}$ and $5 \% \mathrm{CO}_{2}$ for $4 \mathrm{~h}$ at $37{ }^{\circ} \mathrm{C}$. There were three different groups in the experiments: (1) control, (2) OGD exposure and (3) OGD exposure plus treatment with DMED. The control group was always maintained in normal DMEM and put in the incubator under normoxic conditions. To verify the possible involved signaling pathway, DAPT (Notch1 inhibitor, $10 \mu \mathrm{M}$; Sigma-Aldrich) and SN50 (NF-kB inhibitor, $25 \mu \mathrm{g} / \mathrm{mL}$; Sigma-Aldrich) were respectively added into PC12 cells, which were treated with OGD and DMED, followed by measurement of cell viability, apoptosis and oxidative stress.

\section{Cell viability}

Cell viability was analyzed by 3-(4,5-dimethylthiazol-2yl)-2,5-diphenyltetrazolium bromide (MTT) assay [20]. After a period of incubation, PC12 cells $(100 \mu \mathrm{L})$, diluted to $1 \times 10^{5}$ cells $/ \mathrm{mL}$, were seeded into each well of a 96well micro-plate. After treatments, MTT solution was added to the cells with a final concentration of $1 \mathrm{mg} / \mathrm{mL}$ and the mixture was allowed to incubate at $37^{\circ} \mathrm{C}$ for $4 \mathrm{~h}$. Then the supernatant was removed by centrifuging, and the pellets were dissolved in dimethyl sulfoxide (DMSO). The absorbance was measured by spectrophotometry at $570 \mathrm{~nm}$ using an Elx-800uv reader (Bio-Tek Instruments, Winooski, VT, USA).

\section{Cell apoptosis}

Cell apoptosis was assessed by Terminal deoxynucleotidyl transferase (TdT)-mediated dUTP nick end labeling (TUNEL) staining using an in situ cell death detection kit (KeyGEN, Nanjing, China). After treatment, PC12 cells were fixed by $4 \%$ paraformaldehyde at $4{ }^{\circ} \mathrm{C}$ for $30 \mathrm{~min}$, followed by rinsing with phosphate-buffered saline (PBS). Then, PC12 cells were stained according to the manufacture's information. The number of cells was counted under microscopic observation. Cell apoptosis was expressed as the ratio of the number of TUNELpositive cells to the total number of cells, which were counted in five randomly chosen fields.

\section{Quantitative reverse transcription real-time quantitative PCR analysis (qRT-PCR)}

The total RNA of PC12 cells after treatment was isolated using Trizol reagent (Invitrogen) according to the manufacturer's instructions. RNA quality and quantity was measured using a nanodrop spectrophotometer (ND1000, Nanodrop Technologies, Wilmington, DE, USA). RNA was reversely transcribed into cDNA using a Multiscribe RT kit (Applied Biosystems, Foster City, CA, 
USA) in accordance with the recommendation of supplier. Quantification of mRNA expression was performed with Fast SYBR Green (Applied Biosystems) following the supplier's protocol. Primers were designed and synthesized by Sangon Biotech (Shanghai, China). On the basis of the method described previously [21], relative expression of genes were calculated, normalizing to GAPDH.

\section{Western blot analysis}

PC12 cells were lysed with lysis buffer and incubated on ice for $30 \mathrm{~min}$. Then the lysate was centrifuged at $10000 \times g$ at $4{ }^{\circ} \mathrm{C}$ for $20 \mathrm{~min}$, and the supernatant were quantified with $\mathrm{BCA}^{\mathrm{m}}$ Protein Assay Kit (Pierce, Rockford, IL, USA). Proteins ( $30 \mu \mathrm{g} / \mathrm{lane})$ of PC12 cells were subjected to SDS-PAGE and were then transferred to PVDF membranes. The blots were incubated with primary antibodies against B cell lymphoma-2 (Bcl-2, ab194583), Bcl-2-associated X protein (Bax, ab182733), brain-derived neurotrophic factor (BDNF, ab205067), nerve growth factor (NGF, ab52918), Nestin (ab6142), nuclear factor $\kappa \mathrm{B}$ (NF- $\mathrm{kB}, \mathrm{ab28856})$, inhibitor of NF- $\mathrm{kB}$ $\alpha$ (IkB $\alpha, a b 32518)$, GAPDH (ab181603) (all from Abcam, Cambridge, UK), Notch intracellular domain (NICD; 3608, Cell Signaling Technology, Beverly, MA, USA) or Notch1 (sc-32,756; Santa Cruz, Santa Cruz, CA, USA) overnight at $4{ }^{\circ} \mathrm{C}$, and then incubated with secondary antibodies conjugated to horseradish peroxidase at room temperature for $1 \mathrm{~h}$. The bound antibody proteins were visualized by an enhanced chemiluminescence detection system (GE Healthcare Biosciences, Piscataway, NJ, USA). The signals were captured and the intensity of the bands was quantified using Image Lab $^{\text {Tw }}$ software (BioRad, Shanghai, China).

\section{Evaluation of oxidative injury}

Oxidative stress-induced cell injury was evaluated according to the alterations of lactate dehydrogenase (LDH), malordiaolehyde (MDA), superoxide dismutase (SOD) and glutathione peroxidase (GSH-Px). The release of LDH into the medium was measured by LDH assay kit (Bio Vision Inc., Milpitas, CA, USA) at $440 \mathrm{~nm}$. The percentage of LDH leakage was expressed as culture medium OD values / (culture medium OD values + cells homogenate OD values) $\times 100 \%$. For assay of free radicals, the cells were washed with ice-cold PBS. The content of MDA was determined with a Cell MDA assay kit (Jiancheng Bioengineering Institute, Nanjing, China) according to the manufacture's protocol. The absorbance of each sample was measured at $530 \mathrm{~nm}$. SOD activity was measured by the xanthine-xanthine oxidase method. The supernatant was added to xanthine-xanthine oxidase reagent and the mixture was incubated for $40 \mathrm{~min}$ at $37{ }^{\circ} \mathrm{C}$. SDS was added to stop the reaction, followed by measurement of absorbance at $550 \mathrm{~nm}$. GSH-Px activity was measured with Glutathione Peroxidase Assay Kit (Jiang Lai biology, Shanghai, China) following the protocol of supplier.

\section{Detection of tumor necrosis factor-a (TNF-a), interleukin (IL)-6, NADPH oxidase 2 (Nox2) and catalase (CAT) in the hippocampus}

Primary neuronal cells were divided into three groups, namely control, OGD and OGD + DMED groups. After treatments, culture media was collected for measurements of TNF- $\alpha$ and IL- 6 using commercially available enzyme-linked immunosorbent assay (ELISA) kits (R\&D Systems, Minneapolis, MN, USA). The concentration of Nox2 in primary neuronal cells was determined by using an ELISA kit purchased from MyBioSource (San Diego, CA, USA). CAT activity was assessed by using chemical assay kits (Jiancheng Bioengineering Institute).

\section{Statistical analysis}

Results are presented as mean \pm SD of at least three independent experiments. Statistical analysis was performed with the software package SPSS 10.0 (SPSS Inc., Chicago, IL, USA). The significance of differences was determined by two-way analysis of variance (ANOVA) or unpaired two-tailed $\mathrm{t}$-test. The $p$ values less than 0.05 were considered to be statistically significant.

\section{Results}

Effects of DMED on cell viability and apoptosis in PC12 cells under OGD

The results in Fig. 1a showed that OGD treatment timedependently decreased the viability of PC12 cells. Compared with control group, cell viability was significantly decreased at $3 \mathrm{~h}(p<0.01), 6 \mathrm{~h}(p<0.01)$ and $9 \mathrm{~h}$ $(p<0.05)$ after OGD treatment. Interestingly, the OGDinduced reduction of cell viability was significantly alleviated by DMED at $3 \mathrm{~h}(p<0.01), 6 \mathrm{~h}(p<0.05)$ and $9 \mathrm{~h}$ $(p<0.05)$ after OGD. Apoptosis is considered to play a critical role in brain ischemia injury [22]. TUNEL assay was used to analyze apoptosis in PC12 cells. As shown in Fig. 1b, OGD significantly promoted cell apoptosis compared to control group $(p<0.01)$, while DMED obviously alleviated the OGD-induced increase of TUNELpositive cells in PC12 cells $(p<0.05)$. The qRT-PCR and western blot analysis were respectively used to detect the mRNA and protein levels of Bax and Bcl-2. The results showed that the expression of Bax was significantly increased and the expression of $\mathrm{Bcl}-2$ was significantly decreased after the treatment of OGD at both mRNA and protein levels $(p<0.001)$. However the administration of DMED obviously alleviated the effect of OGD on PC12 cells compared with OGD group $(p<0.05$ or $p<0.01$; Fig. 1c-d). 


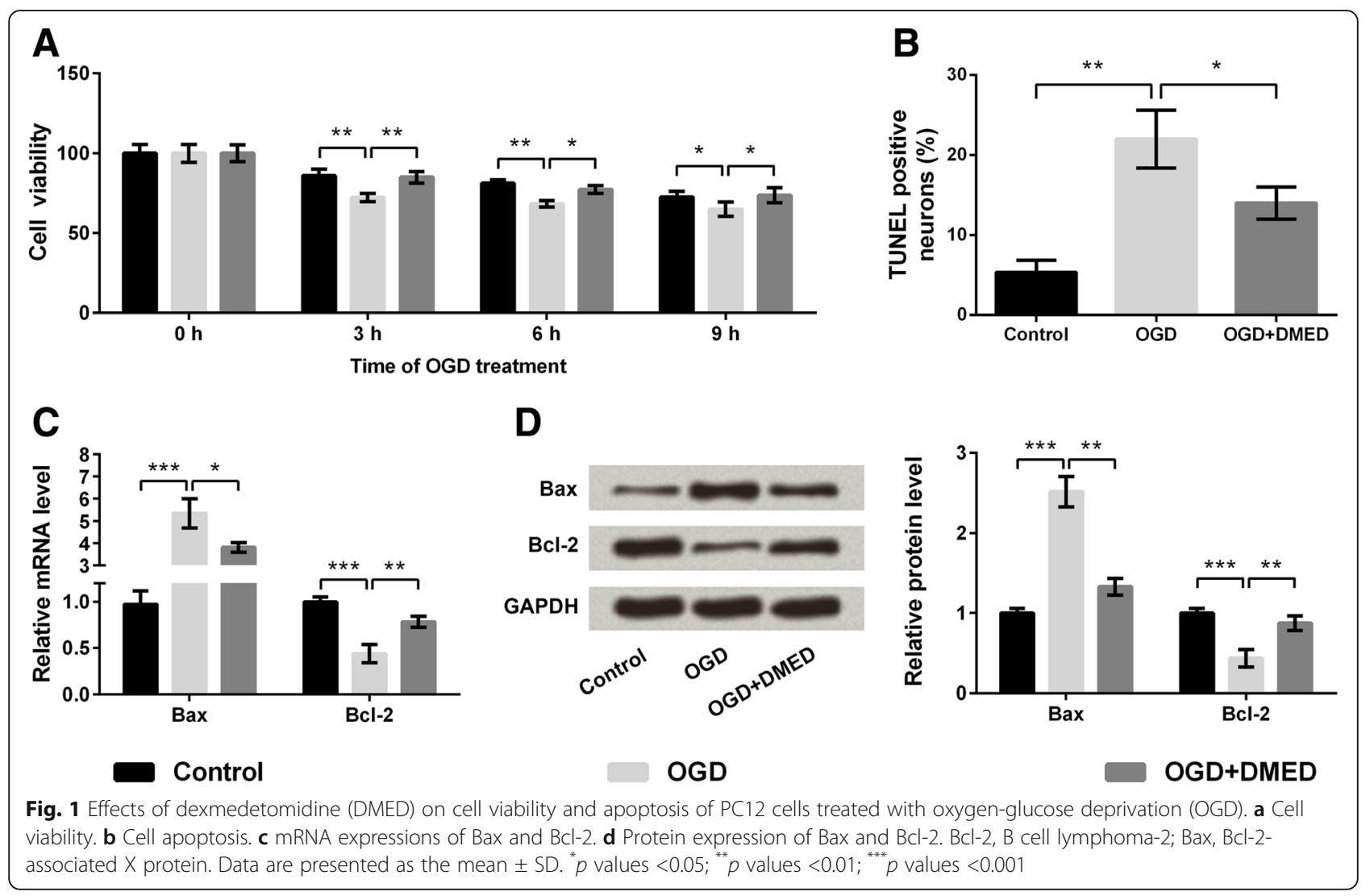

\section{Effects of DMED on oxidative stress in PC12 cells under OGD}

Oxidative stress induced by OGD can lead to the death of PC12 cells [23], thus the related indicators of oxidative stress, including LDH, MDA, SOD and GSH-Px were all evaluated. As shown in Fig. 2a-b, OGD treatment significantly increased LDH leakage into the medium and the content of MDA compared with control group $(p<0.01$ or $p<0.001)$, while DMED markedly attenuated the increases compared with OGD group ( $p<0.05$ or $p<0.01$ ). Conversely, the activity of SOD and GSH-Px were both reduced by OGD compared with control group $(p<0.05$ or $p<0.01)$, whereas these reductions were ameliorated by DMED compared with OGD group $(p<0.05$, Fig. $2 \mathrm{c}-\mathrm{d})$.

\section{DMED promoted the repair of neurons after ischemia anoxic injury}

The expressions of BDNF, NGF, and Nestin were analyzed by qRT-PCR and western blot analysis. The results showed that OGD treatment significantly decreased the mRNA levels of BDNF, NGF and Nestin in PC12 cells compared with control group $(p<0.01)$. However, DMED alleviated the OGD-induced decreases of BDNF, NGF and Nestin levels compared with OGD group $(p<0.05)$, indicating that DMED promoted the repair of neuronal impairment induced by OGD (Fig. 3a-c). Results in Fig. 3d also proved the protective effect of DMED on neuronal impairment.

\section{Notch/NF-KB was involved in the protection of DMED on OGD-induced nerve injury}

The expressions of key kinases involved in Notch and NF-kB signaling pathways were analyzed by qRT-PCR and western blot analysis. The results showed that OGD treatment significantly increased the mRNA and protein levels of Notch1 and NICD compared with control group $(p<0.001)$, but the OGD-induced up-regulations of Notch1 and NICD were alleviated by DMED $(p<0.05$ or $p<0.01$ ), indicating that DMED inhibited the OGDinduced activation of Notch pathway (Fig. 4a-d). Similarly, the marked up-regulations of NF-kB and IkB $\alpha$ at mRNA and protein levels after treatment of OGD $(p$ $<0.01$ or $p<0.001$ ) were both significantly alleviated by DMED treatment $(p<0.05$ or $p<0.01)$, indicating that DMED inhibited the OGD-induced activation of NF-kB pathway (Fig. 4e-h).

Inhibition of Notch or NF-кB pathway augmented the protective effect of DMED on OGD-induced cell injury The effects of DMED on OGD-induced cell injury were assessed again with or without the presence of Notch 

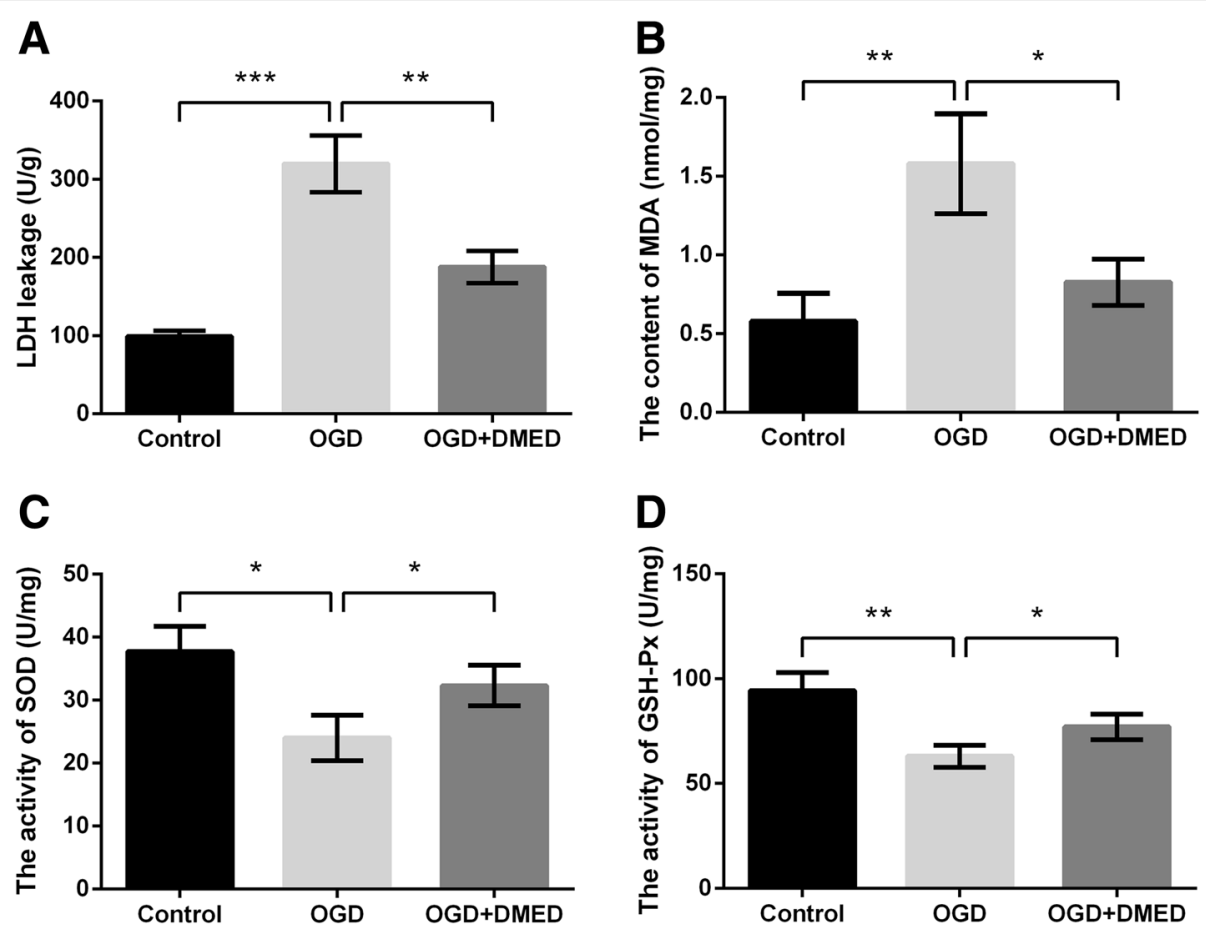

Fig. 2 Effects of dexmedetomidine (DMED) on oxidative stress in PC12 cells treated with oxygen-glucose deprivation (OGD). a Lactate dehydrogenase $(\mathrm{LDH})$ leakage. $\mathbf{b}$ Content of malordiaolehyde (MDA). c Activity of superoxide dismutase (SOD). $\mathbf{d}$ Activity of glutathione peroxidase (GSH-Px). Data are presented as the mean \pm SD. ${ }^{*} p$ values $<0.05 ;{ }^{* *} p$ values $<0.01 ;{ }^{* * *} p$ values $<0.001$
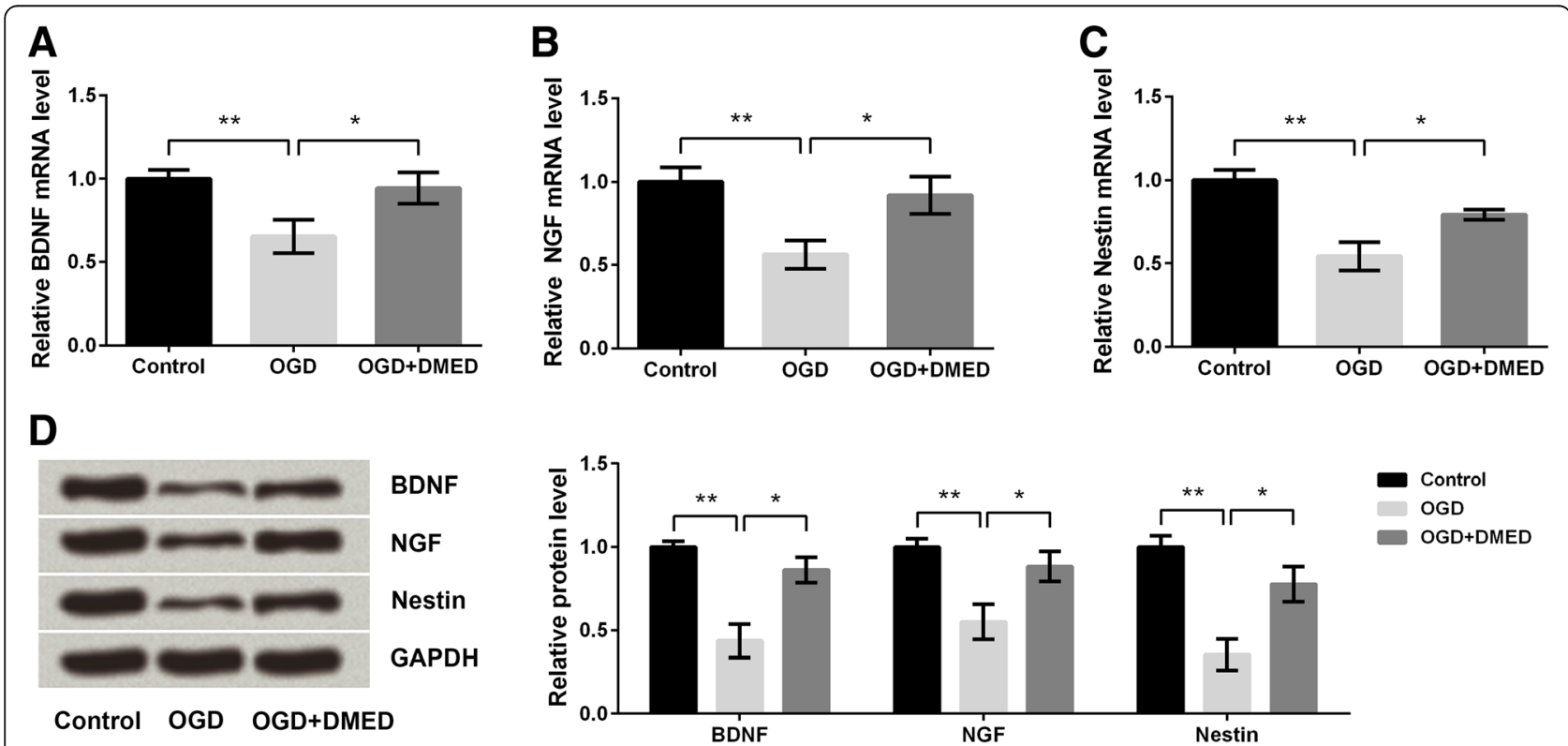

Fig. 3 Effects of dexmedetomidine (DMED) on the repair of neurons after the treatment with oxygen-glucose deprivation (OGD). a The mRNA level of brain-derived neurotrophic factor (BDNF). $\mathbf{b}$ The mRNA level of nerve growth factor (NGF). $\mathbf{c}$ The mRNA level of Nestin. $\mathbf{d}$ Protein levels of BDNF, NGF and Nestin. Data are presented as the mean \pm SD. ${ }^{*} p$ values $<0.05 ;{ }^{* *} p$ values $<0.01$ 


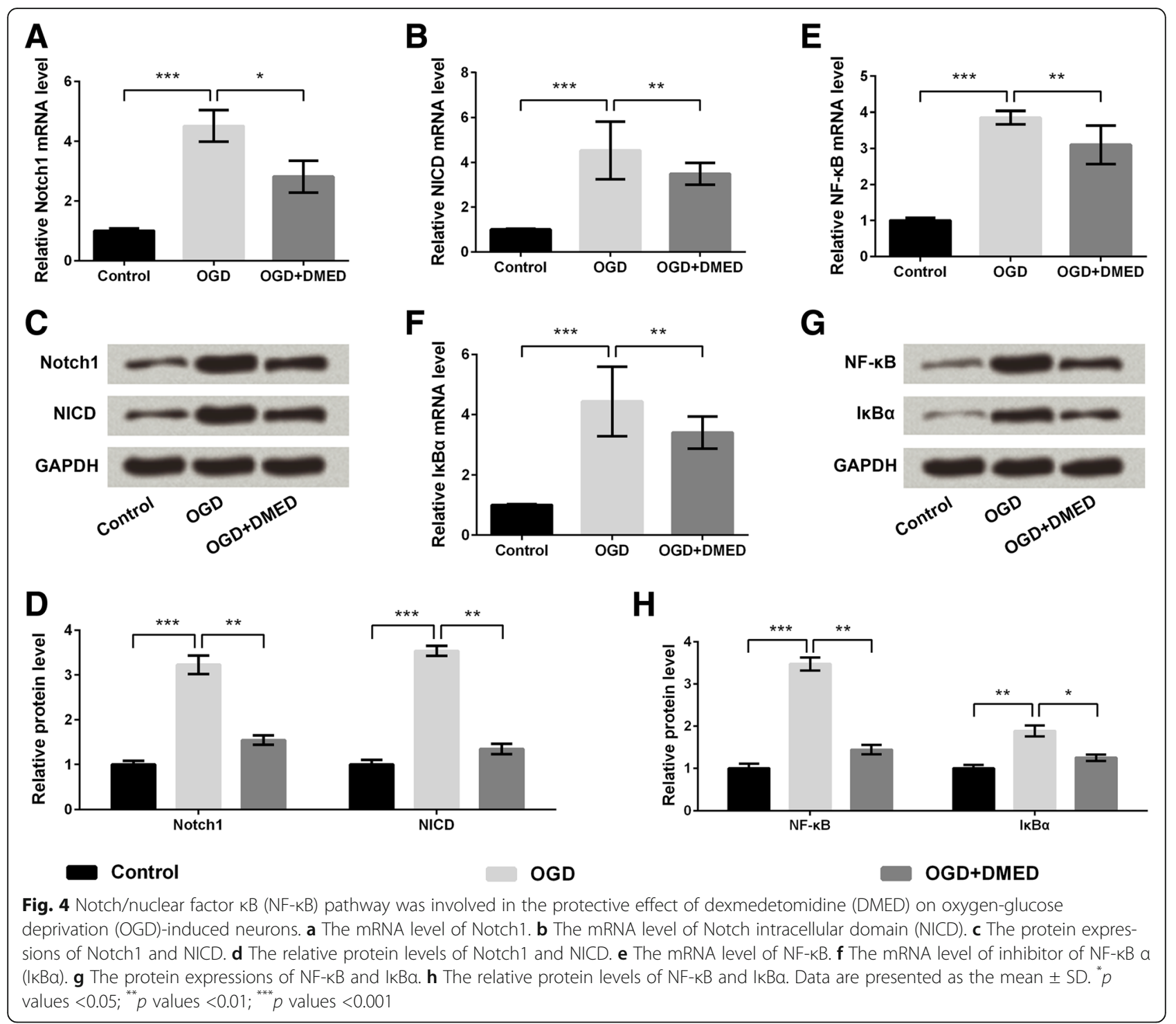

inhibitor (DAPT) or NF-kB inhibitor (SN50). Results in Fig. $5 \mathrm{a}$ and e-f showed cell viability at $6 \mathrm{~h}$ after OGD as well as activities of SOD and GSH-Px was enhanced by treatment of DAPT or SN50 compared with OGD + DMED group $(p<0.05)$. Cell apoptosis as well as levels of $\mathrm{LDH}$ and MDA was markedly reduced by treatment of DAPT or SN50 compared with OGD + DMED group $(p<0.05$, Fig. $5 \mathrm{~b}-\mathrm{d})$. Results indicated that inhibition of Notch or NF-KB pathway could enhanced the protective effects of DMED on OGDinduced cell injury in PC12 cells.

\section{OGD-induced cell injury in primary neuronal cells was alleviated by DMED}

The protective effects of DMED on OGD-induced cell injury were verified in primary neuronal cells. The cell injury was evaluated according to the alterations of IL-6,
TNF- $\alpha$, Nox2 and CAT. Results in Fig. 6a-c showed levels of IL-6, TNF- $\alpha$ and Nox 2 were elevated by OGD $(p<0.01$ or $p<0.001)$, whereas the increases were alleviated by DMED $(p<0.05$ or $p<0.01)$. Conversely, OGD decreased activity of CAT $(p<0.01)$ but the decrease was alleviated by DMED $(p<0.05)$.

\section{Discussion}

DMED is a highly selective, short acting central $\alpha_{2}$ adrenergic receptor agonist, which binds to transmembrane $G$ protein-binding receptors in brain and spinal cord tissues [24, 25]. It has been reported that DMED has neuroprotective effects [26]. Therefore in the present study, we explored the neuroprotective effects of DMED on OGD-induced ischemic injury in PC12 cells. The degree of cell injury induced by OGD was measured by MTT assay and LDH release in this 



D

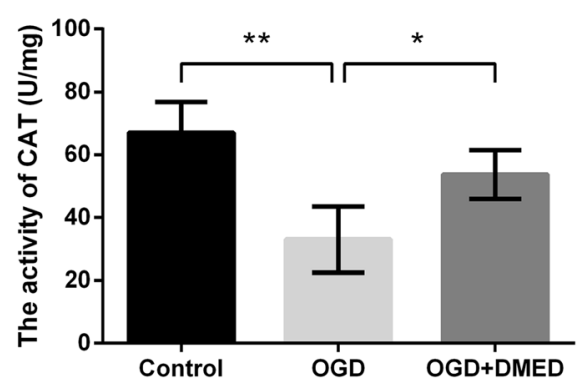

Fig. 6 Effects of dexmedetomidine (DMED) on primary neuronal cells treated with oxygen-glucose deprivation (OGD). a The level of interleukin (IL)-6. b The level of tumor necrosis factor-a (TNF-a). $\mathbf{c}$ The level of NADPH oxidase 2 (Nox2). $\mathbf{d}$ The level of catalase (CAT). Data are presented as the mean $\pm S D$. ${ }^{*} p$ values $<0.05 ;{ }^{* *} p$ values $<0.01 ;{ }^{* * *} p$ values $<0.001$ 
study. MTT is a substrate for intracellular and cellular membrane oxidoreductases [27], and the number of its reductive form has close relationship with the amount of living cells. Some studies have found that the degree of LDH leakage has correlation with cell membrane damage [27, 28]. In this study, the decreased cell viability and elevated levels of LDH were discovered in PC12 cells treated with OGD, which was in accordance with the results in a previous study [29]. However, the administration of DMED significantly alleviated the reduction of cell viability and inhibited the release of $\mathrm{LDH}$, indicating that DMED improved OGD-induced injury in PC12 cells.

Apoptosis is a form of cell death that is mediated by many factors, including oxidative stress, excitotoxicity and so on [30, 31]. Bcl-2 and Bax, the members of the Bcl-2 family of proteins, can mediate apoptosis and attenuate caspase-3 activation [32]. To further understand the mechanism of apoptosis, the expression levels of Bcl-2 and Bax were analyzed in our study. The results showed that after OGD-treatment, the mRNA and protein expression of Bax was significantly increased and that of $\mathrm{Bcl}-2$ was decreased. However, the treatment of DMED nearly reserved the levels of Bcl-2 and Bax to normal, providing an explanation for the effect of DMED on cell apoptosis after OGD.

Available studies have discovered that oxidative stress plays a critical role in the pathogenesis of many neurological diseases such as Alzheimer's disease and stroke [33]. Lipid peroxidation and oxygen free radical play an important role in the development of injuries in the central nervous system. SOD is usually considered to be the important line of defense against cell injury caused by cytotoxic reactive oxygen species [34]. The results in this study showed that OGD-treatment led to an obvious increase of MDA and a decrease of SOD and GSH-Px activity. Our results were in accordance with a previous research, which discovered decreased SOD and GSH-Px activity in the ischemic rats [35]. However, the treatment of DMED alleviated the enhancement of MDA and increased the activities of SOD and GSH-Px.

Neurotrophic factors, including BDNF, NGF and Nestin, are essential for the development and survival of neurons, as well as the maintenance and plasticity of brain [36]. BDNF, NGF or combination of these two factors were reported to induce neuronal differentiation of neural stem cells [37]. In our study, expressions of these three factors were all down-regulated by OGD whereas the down-regulations were all ameliorated by DMED treatment, indicating the neuroprotection of DMED.

Notch proteins are a family of single-pass transmembrane heterodimeric receptors, which participate in cell proliferation or differentiation in many tissues [38]. Notch signaling pathway is one of the most conserved pathways with plenty of functions [39], which can regulate the survival and apoptosis of neural stem cells during the development of the brain. The expression and activation of Notch signaling have been reported in different diseases. Increasing evidence discovered that the disorders of Notch signaling were the main cause for the activation of many oncogenic pathways, such as NF- $\mathrm{kB}$ $[40,41]$. The results in the present study showed that OGD treatment significantly increased the levels of Notch1 and NICD, indicating that OGD activated the Notch pathway, while DMED inhibited the activation of Notch pathway. The similar results were also found in NF- $\kappa B$ pathway, indicating that Notch/NF- $\kappa B$ pathway was involved in the protection of DMED on OGDinduced nerve injury. Further studies performed with Notch or NF- $\kappa B$ inhibitor proved the involvements of the Notch/NF- $k B$ pathway in the neuroprotection of DMED in OGD-induced neuronal injury.

TNF- $\alpha$ and IL- 6 are two inflammatory factors that could be induced by hypoxia [42]. Nox, expressed throughout the central nervous system, are a major source of brain ROS [43]. CAT is part of endogenous anti-oxidant system and its up-regulation indicates enhancement of antioxidant system [44]. In our study, the protective effects of DMED were also proved in the primary neuronal cells. The OGD-induced increases of IL-6, TNF- $\alpha$ and Nox2 level as well as decrease of CAT activity were all ameliorated by DMED treatment, consolidating the neuroprotection of DMED in OGD-induced cell injury.

\section{Conclusion}

In summary, DMED had protective effect on OGDinduced cell injury of $\mathrm{PC} 12$ and primary neuronal cells. Such protection of cells against ischemia might depend on its anti-apoptotic and anti-oxidative activity and the inhibition of Notch/NF-кB activation. Our findings suggested that DMED could be used as a potential therapeutic for cerebral ischemia.

\section{Abbreviations \\ DMED: Dexmedetomidine; DMSO: Dimethyl sulfoxide; GSH-Px: Glutathione peroxidase; LDH: Lactate dehydrogenase; MDA: Malordiaolehyde; \\ OGD: Oxygen and glucose deprivation; SOD: Superoxide dismutase; \\ TdT: Terminal deoxynucleotidyl transferase \\ Acknowledgements \\ None. \\ Funding \\ The research wasn't supported by any foundation. \\ Availability of data and materials \\ The datasets generated and analysed during the current study are available from the corresponding author on reasonable request.}

\section{Authors' contributions}

YJL have been involved in the design of the research, the performance of the experiments, the analysis and interpretation of the data as well as the drafting of the article. DYW and YJY have been involved in the performance 
of the experiments, analysis and interpretation of data. WFL have been involved in the conception and design and revising it critically for important intellectual content. All authors read and approved the final manuscript.

\section{Ethics approval and consent to participate}

Not applicable.

\section{Consent for publication}

Not applicable.

\section{Competing interests}

The authors declare that they have no competing interests.

\section{Publisher's Note}

Springer Nature remains neutral with regard to jurisdictional claims in published maps and institutional affiliations.

\section{Author details}

'Department of Anesthesiology, Qilu Hospital of Shandong University, No. 107, Wenhua West Road, Jinan, Shandong 250012, China. ${ }^{2}$ Department of Anesthesiology, Jinan Central Hospital Affiliated to Shandong University, Jinan, Shandong 250013, China.

\section{Received: 30 March 2017 Accepted: 25 August 2017}

Published online: 30 August 2017

\section{References}

1. Maier O, Menze BH, Gablentz JVD, Häni L, Heinrich MP, Liebrand M, Winzeck S, Basit A, Bentley P, Chen L. ISLES 2015 - A public evaluation benchmark for ischemic stroke lesion segmentation from multispectral MRI. Med Image Anal. 2017;35:250.

2. Shi Z, Wu D, Yao J-P, Yao X, Huang Z, Li P, Wan J-B, He C, Su H. Protection against oxygen-glucose deprivation/reperfusion injury in cortical neurons by combining omega-3 polyunsaturated acid with lyciumbarbarum polysaccharide. Nutrients. 2016;8(1):41.

3. Seidenstein MAH, Barone FC, Lytton WW. Computer modeling of ischemic stroke. Drug Discov Today Dis Models. 2017;10(3):32015.

4. Chao G, Wang S, Duan J, Na J, Zhu Y, Yi D, Yue G, Guo W, Ying Y, Xi M. Protocatechualdehyde protects against cerebral ischemia-reperfusioninduced oxidative injury via protein Kinase $\mathrm{C} \varepsilon / \mathrm{Nrf2} / \mathrm{HO}-1$ pathway. $\mathrm{Mol}$ Neurobiol. 2017;54(2):833.

5. Meng S, Su Z, Liu Z, Wang N, Wang Z. Rac1 contributes to cerebral ischemia reperfusion-induced injury in mice by regulation of Notch2. Neuroscience. 2015;306:100-14

6. Li P, Shen M, Feng G, Wu J, Zhang J, Teng F, Zhang C. An antagomir to MicroRNA-106b-5p ameliorates cerebral ischemia and reperfusion injury in rats via inhibiting apoptosis and oxidative stress. Mol Neurobiol. 2017;54(4): 2901-21.

7. Zhao JH, Meng XL, Zhang J, Li YL, Li YJ, Fan ZM. Oxygen glucose deprivation post-conditioning protects cortical neurons against oxygenglucose deprivation injury: role of HSP70 and inhibition of apoptosis. J Huazhong Univ Sci Technolog Med Sci. 2014;34(1):18-22.

8. Ryu S, Seol GH, Park H, Choi IY. Trans-anethole protects cortical neuronal cells against oxygen-glucose deprivation/reoxygenation. Neurol Sci. 2014;35(10):1541-7.

9. Tasca $\mathrm{Cl}$, Dal-Cim T, Cimarosti H. In vitro oxygen-glucose deprivation to study ischemic cell death. Methods Mol Biol. 2015;1254:197-210.

10. Vaudry D, Stork PJ, Lazarovici P, Eiden LE. Signaling pathways for PC12 cell differentiation: making the right connections. Science (New York, NY). 2002;296(5573):1648-9.

11. Hillion JA, Takahashi K, Maric D, Ruetzler C, Barker JL, Hallenbeck JM Development of an ischemic tolerance model in a PC12 cell line. J Cereb Blood Flow Metab. 2005:25(2):154-62

12. Shafer TJ, Atchison WD. Transmitter, ion channel and receptor properties of pheochromocytoma (PC12) cells: a model for neurotoxicological studies. Neurotoxicology. 1991;12(3):473-92

13. Fu XY, Yang MF, Cao MZ, Li DW, Yang XY, Sun JY, Zhang ZY, Mao LL, Zhang S, Wang FZ. Strategy to suppress oxidative damage-induced neurotoxicity in PC12 cells by Curcumin: the role of ROS-mediated DNA damage and the MAPK and AKT pathways. Mol Neurobiol. 2016;53(1):369-78.
14. Zhang D, Wang Z, Sheng C, Peng W, Shan H, Wei G, Chen S. Icariin prevents amyloid beta-induced apoptosis via the PI3K/Akt pathway in PC-12 cells. Evid Based Complement Alternat Med. 2015;2015:235265.

15. Leutz S, Steiner B, Marques CA, Haass C, Muller WE, Eckert A. Reduction of trophic support enhances apoptosis in PC12 cells expressing Alzheimer's APP mutation and sensitizes cells to staurosporine-induced cell death. J Mol Neurosci. 2002;18(3):189-201.

16. Endesfelder S, Makki H, Haefen CV, Spies CD, Bührer C, Sifringer M. Neuroprotective effects of dexmedetomidine against hyperoxia-induced injury in the developing rat brain. PLoS One. 2017;12(2):e0171498.

17. Jie L, Wei O, Zou XH, Yin Y, Wu JL. Effect of dexmedetomidine on hippocampal neuron development and BDNF-TrkB signal expression in neonatal rats. Neuropsychiatr Dis Treat. 2016:12:3153-9.

18. Prielipp RC, Wall MH, Tobin JR, Groban L, Cannon MA, Fahey FH, Gage HD, Stump DA, James RL, Bennett J, et al. Dexmedetomidine-induced sedation in volunteers decreases regional and global cerebral blood flow. Anesth Analg. 2002;95(4):1052-9. table of contents

19. Liu J, Du Q, Zhu H, Li Y, Liu M, Yu S, Wang S. Dexmedetomidine reduces hypoxia/reoxygenation injury by regulating mitochondrial fission in rat hippocampal neurons. Int J Clin Exp Med. 2017;10(4):6861-8.

20. Mosmann T. Rapid colorimetric assay for cellular growth and survival: application to proliferation and cytotoxicity assays. J Immunol Methods. 1983;65(1-2):55-63.

21. Livak KJ, Schmittgen TD. Analysis of relative gene expression data using real-time quantitative PCR and the 2(-Delta Delta C(T)) Method. Methods. 2001;25(4):402-8.

22. Esmat AY, Said MM, Khalil SA. Aloin: a natural antitumor anthraquinone glycoside with iron chelating and non-atherogenic activities. Pharm Biol. 2015;53(1):138-46

23. Hong S, Son MR, Yun K, Lee WT, Park KA, Lee JE. Retroviral expression of human arginine decarboxylase reduces oxidative stress injury in mouse cortical astrocytes. BMC Neurosci. 2014;15:99.

24. Tan JA, Ho KM. Use of dexmedetomidine as a sedative and analgesic agent in critically ill adult patients: a meta-analysis. Intensive Care Med. 2010;36(6):926-39.

25. Farag E, Argalious M, Abd-Elsayed A, Ebrahim Z, Doyle DJ. The use of dexmedetomidine in anesthesia and intensive care: a review. Curr Pharm Des. 2012;18(38):6257-65.

26. Dahmani S, Rouelle D, Gressens P, Mantz J. Effects of dexmedetomidine on hippocampal focal adhesion kinase tyrosine phosphorylation in physiologic and ischemic conditions. Anesthesiology. 2005;103(5):969-77.

27. Wu JB, Song NN, Wei XB, Guan HS, Zhang XM. Protective effects of paeonol on cultured rat hippocampal neurons against oxygen-glucose deprivationinduced injury. J Neurol Sci. 2008;264(1-2):50-5.

28. Xu W, Zha RP, Wang WY, Wang YP. Effects of scutellarin on PKCgamma in PC12 cell injury induced by oxygen and glucose deprivation. Acta Pharmacol Sin. 2007:28(10):1573-9.

29. Fuerer C, Nusse R, Berge DT. Wnt signalling in development and disease. EMBO Rep. 2008:9(2):134-8.

30. Vannucci RC, Towfighi J, Vannucci SJ. Secondary energy failure after cerebral hypoxia-ischemia in the immature rat. J Cereb Blood Flow Metab. 2004;24(10):1090-7.

31. Northington FJ, Chavez-Valdez R, Martin LJ. Neuronal cell death in neonatal hypoxia-ischemia. Ann Neurol. 2011;69(5):743-58.

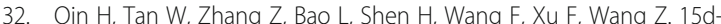
prostaglandin $\mathrm{J} 2$ protects cortical neurons against oxygen-glucose deprivation/reoxygenation injury: involvement of inhibiting autophagy through upregulation of Bcl-2. Cell Mol Neurobiol. 2015;35(3):303-12.

33. Chong ZZ, Li F, Maiese K. Oxidative stress in the brain: novel cellular targets that govern survival during neurodegenerative disease. Prog Neurobiol. 2005;75(3):207-46.

34. Korenic A, Boltze J, Deten A, Peters M, Andjus P, Radenovic L. Astrocytic mitochondrial membrane hyperpolarization following extended oxygen and glucose deprivation. PLoS One. 2014;9(2):e90697.

35. Yanpallewar SU, Rai S, Kumar M, Acharya SB. Evaluation of antioxidant and neuroprotective effect of Ocimum sanctum on transient cerebral ischemia and long-term cerebral hypoperfusion. Pharmacol Biochem Behav. 2004:79(1):155-64.

36. Ivanov AD, Tukhbatova GR, Salozhin SV, Markevich VA. NGF but not BDNF overexpression protects hippocampal LTP from $\beta$-amyloid-induced impairment. Neuroscience. 2015;289:114-22. 
37. Liu F, Xuan A, Chen Y, Zhang J, Xu L, Yan Q, Long D. Combined effect of nerve growth factor and brain銢慸erived neurotrophic factor on neuronal differentiation of neural stem cells and the potential molecular mechanisms. Mol Med Rep. 2014;10(4):1739-45.

38. Maillard I, Fang T, Pear WS. Regulation of lymphoid development, differentiation, and function by the Notch pathway. Annu Rev Immunol. 2005;23:945-74.

39. Andersson ER, Sandberg R, Lendahl U. Notch signaling: simplicity in design, versatility in function. Development (Cambridge, England). 2011; 138(17):3593-612.

40. Espinosa L, Cathelin S, D'Altri T, Trimarchi T, Statnikov A, Guiu J, Rodilla V, Ingles-Esteve J, Nomdedeu J, Bellosillo B, et al. The Notch/Hes1 pathway sustains NF-kappaB activation through CYLD repression in T cell leukemia. Cancer Cell. 2010;18(3):268-81.

41. Screpanti I, Bellavia D, Campese AF, Frati L, Gulino A. Notch, a unifying target in T-cell acute lymphoblastic leukemia? Trends Mol Med. 2003;9(1):30-5.

42. Zhao C, Liu J, Zhang M, Wu Y. Semaphorin 3A deficiency improves hypoxiainduced myocardial injury via resisting inflammation and cardiomyocytes apoptosis. Cellular Mol Biol (Noisy-le-Grand, France). 2016;62(2):8.

43. Dickinson BC, Peltier J, Stone D, Schaffer DV, Chang CJ. Nox2 redox signaling maintains essential cell populations in the brain. Nat Chem Biol. 2011;7(2):106-12.

44. Goshan V, Mundugaru R, Prakash N, Bhat S, Basavaiah R: Evaluation of neuro-protective activity of Brihatvata Chinthamani Rasa. 2015.

\section{Submit your next manuscript to BioMed Central and we will help you at every step:}

- We accept pre-submission inquiries

- Our selector tool helps you to find the most relevant journal

- We provide round the clock customer support

- Convenient online submission

- Thorough peer review

- Inclusion in PubMed and all major indexing services

- Maximum visibility for your research

Submit your manuscript at www.biomedcentral.com/submit 